\title{
The Effect of Food Intake on the Incidence of Malnutrition in Toddlers in the Work Area of the Kertosari Health Center, Banyuwangi Regency
}

\author{
Endang Sri Purwanti Wulandari, Erma Sulistyaningsih*, \\ Ancah Caesarina Novi Marchianti \\ Universitas Jember, Indonesia \\ *sulistyaningsih.fk@unej.ac.id
}

\begin{abstract}
Malnutrition is an actual problem that occurs in Banyuwangi Regency. One of the factors that play a role in causing malnutrition is the pattern of food intake. According to WHO data globally as $>50 \%$ of infant and child deaths are related to malnutrition. Based on data from the East Java Provincial Health Office in 2017, Banyuwangi Regency was in the first place with the highest incidence of malnutrition, as many as 526 cases. This study aims to determine the effect of food intake patterns on malnutrition incidence in toddlers in the working area of Kertosari Health Care. This study used a cross-sectional method with a research population of 30 toddlers. The data were obtained from validated questionnaires and food intake measurements using a 24 hours food recall form. Samples in this study as many as 30 malnourished toddlers and spread in the Kertosari Health Care working area. The data were analyzed using descriptive analysis techniques and ordinal logistic regression influence tests. The results of the study showed that energy intake patterns $(p=0.032)$, protein intake patterns $(\mathrm{p}=0.026)$, fat intake patterns $(\mathrm{p}=0.026)$, carbohydrate intake patterns $(\mathrm{p}=0.014)$, zinc intake patterns $(\mathrm{p}=0.043)$ and calcium intake patterns $(\mathrm{p}=0.026)$ with the incidence of malnutrition in toddlers. All determinants of food intake patterns have a significant effect on the incidence of malnutrition in toddlers.
\end{abstract}

Keywords: Food Intake, Malnutrition, Toddlers 


\section{STRADA Jurnal Ilmiah Kesehatan}

DOI: $10.30994 /$ sjik.v9i2.530

ISSN: 2252-3847 (print); 2614-350X (online)

Vol.9 No.2 November 2020 Page.1740-1746

\section{BACKGROUND}

Malnutrition is a condition in which a person's nutrition is deficient, far below the average standard, characterized by a very thin condition or the appearance of signs of hunger edema. Malnutrition status is measured based on weight measurement by Height (BB/U) less than the standard determined by the World Health Organization (WHO) of -3z (Ministry of Health RI, 2011). Malnutrition is a form of long-term reflection of the problem of malnutrition in a matter of years. The prevalence of malnutrition based on $\mathrm{BB} / \mathrm{U}$ indicators in Indonesia is included in public health problems close to high prevalence. Based on malnutrition management, the indicator to determine that the child should receive treatment is a $\mathrm{BB} / \mathrm{TB}$ indicator with a Z-Score value of <-3SD and is characterized by clinical symptoms that appear to be very thin and the presence of edema in both insteps to the whole body (Ministry of Health RI, 2011).

According to H.L. Blum in Notoatmodjo (2012), health status is influenced by 4 main factors: behavior, environment, health services, and heredity. The four determinants interact with each other and affect a person's health status. Predisposing factors for nutritional problems include behavioral factors, experience related to health and nutrition services, individual factors related to personal and family, as well as environmental factors (Ministry of Health RI, 2018).

Behavioral factors include dietary intake and dietary patterns. The dietary intake pattern includes protein-energy intake, fat energy intake, carbohydrate energy intake, zinc energy intake, and calcium energy intake. Consumption of wrong foods affects the deviation of nutrients in the body. This deviation, in turn, affects physiological and biological functions. These functions result in a level of physical growth and immunological abilities. Karyadi (1985) states that food parenting is a way of caring for children concerning feeding (Fitayani, 2014).

The results of the National Nutritional Status Determination survey in 2017 stated that the percentage of malnutrition in East Java was 2.9\%, undernutrition was 12.6\%, and the prevalence of underweight was $15.5 \%$. Banyuwangi Regency is in the first place with the highest incidence of malnutrition, with 526 cases (Banyuwangi Health Office, 2017). Although the number of malnutrition decreased, the percentage of malnutrition incidence increased from $0.55 \%$ in 2017 to $0.56 \%$ in 2018 . In this study, an analysis of the effect of food intake on malnutrition incidence in children under five was conducted. The toddler period is the peak period of cell growth and development, where health problems will affect the growth and development process. This research will be conducted in areas with the highest incidence of malnutrition in Banyuwangi in 2019, namely in the Kertosari Health Center working area (Banyuwangi Health Office, 2019).

\section{METHODS}

This study used a quantitative approach with a cross-sectional research design. In this study, the population and sample were all malnourished toddlers at Kertosari Health Center, which contains 30 toddlers. The sampling technique used was total sampling with ordinal logistic regression analysis. This research has received research ethics permit from the Health Research Ethics Commission, Faculty of Dentistry, University of Jember No.896 / UN25.8 / KEPK / DL / 2020. This study's dependent variable was malnutrition, while the study's independent variable was dietary intake (protein intake, fat intake, carbohydrate intake, zinc intake, and calcium intake). The data were collected on the respondents' age and gender using a questionnaire, while data collection on food intake patterns used the 24-hour food recall form. The study's inclusion criteria were respondents who were in the working 


\section{STRADA Jurnal Ilmiah Kesehatan}

DOI: $10.30994 /$ sjik.v9i2.530

ISSN: 2252-3847 (print); 2614-350X (online)

Vol.9 No.2 November 2020 Page.1740-1746

area of the Kertosari Public Health Center, Banyuwangi Regency, namely mothers and toddlers, toddlers who were recorded in the Integrated Healthcare Center report and were willing to be research respondents. Meanwhile, the exclusion criteria were toddlers who were either sick or being treated at the hospital, toddlers who did not live in the research area, for example these toddlers routinely came to their grandmother's house only during the day but at night returned to their home in the area, toddlers who only come to the integrated healthcare center during the weighing month for vitamin A, but they come from other areas.

The statistical analysis was conducted using statistical software packages for social science (SPSS) with a significant level $(p<0.05)$.

\section{RESULT}

The results of the descriptive analysis of the research subjects' characteristics in each group can be seen in table 1 .

Table 1. Characteristics of age and Gender

\begin{tabular}{lccc}
\hline & & \multicolumn{2}{c}{ Kertosari Health Center } \\
\hline \multirow{3}{*}{ Anser } & Frequency & Percentage \\
\hline \multirow{3}{*}{ Gender } & $0-24$ months & 9 & $30,00 \%$ \\
& $25-36$ months & 8 & $26,67 \%$ \\
& $37-59$ months & 13 & $43,33 \%$ \\
\cline { 2 - 4 } & Amount & $\mathbf{3 0}$ & $\mathbf{1 0 0 , 0 0 \%}$ \\
\cline { 2 - 4 } & Male & 18 & $60 \%$ \\
\cline { 2 - 4 } & Female & 12 & $40 \%$ \\
\hline
\end{tabular}

Based on table 1, it can also be seen that the majority of respondents at the Kertosari Health Center aged 37-59 months were 13 people or $43.33 \%$, while the minority at the age of 25 36 months were 8 people or $26.67 \%$. It can also be seen that the majority of respondents at the Kertosari Health Center were male, namely as many as 18 people or $60.00 \%$, while the minority was female, namely as many as 12 people or $40.00 \%$.

Table 2. Recapitulation of Estimated Results at Kertosari Health Center

\begin{tabular}{lcccc}
\hline $\begin{array}{c}\text { Independent } \\
\text { variable }\end{array}$ & $\mathbf{a}$ & $\mathbf{b}$ & t-count & p-value \\
\hline Energy & 2,750 & $-0,375$ & $-2,261$ & 0,032 \\
\hline Protein & 0,742 & 0,402 & 2,356 & 0,026 \\
\hline Fat & 0,742 & 0,402 & 2,356 & 0,026 \\
\hline Carbohydrate & 3,000 & $-0,450$ & $-2,634$ & 0,014 \\
\hline Zinc & 0,861 & 0,361 & 2,118 & 0,043 \\
\hline Calsium & 0,742 & 0,402 & 2,356 & 0,026 \\
\hline
\end{tabular}

Table 2 shows that carbohydrate intake has the most significant effect on the incidence of malnutrition in children under five, indicated by the value of $\mathrm{p}=0.014<0.05$. 


\section{STRADA Jurnal Ilmiah Kesehatan}

DOI: $10.30994 /$ sjik.v9i2.530

ISSN: 2252-3847 (print); 2614-350X (online)

Vol.9 No.2 November 2020 Page.1740-1746

\section{DISCUSSION}

Based on the table. 1, the majority of respondents aged 37-59 months were 13 people or $43.33 \%$ and were male, namely 18 people or $60.00 \%$. The results showed a significant influence between food intake and malnutrition in toddlers with a p-value $<0.05$ for each independent variable. Low intake results in abnormal nutritional status (Solihin, Anwar, \& Sukandar, 2013). Based on Table 2. from the level of significance, it is known that the pattern of energy intake $(p=0.032)$, the pattern of protein intake $(p=0.026)$, the pattern of fat intake $(\mathrm{p}=0.026)$, the pattern of carbohydrate intake $(\mathrm{p}=0.014)$, the pattern of zinc intake $(\mathrm{p}=0.043)$ and calcium intake patterns $(\mathrm{p}=0.026)$ with the incidence of malnutrition in toddlers. The food intake factors discussed in this study were energy intake, protein intake, fat intake, carbohydrate intake, calcium intake, and zinc intake. The growth and development require the intake of essential nutrients, including energy, protein, fat, carbohydrates, minerals, and water, which should be consumed in a balanced manner according to their age needs. The nutrients are especially needed during the growth period, namely during infancy, toddlers, and adolescents who require many nutritional intakes (Arisman, 2009).

The description of the statistical analysis results shows that there is an influence between energy intake and the incidence of malnutrition in toddlers. This study's results are not in line with previous research, which shows that there is no relationship between energy intake and nutritional status of children under five based on body weight compared to height (Deiby Olivia, Nita R, \& Nova, 2018). Many factors cause the incidence of malnutrition due to lack of energy intake in the working area of Gitik Health Center. The contributing factor is the condition of household food resistance caused by parental education, type of work of parents, and lack of daily income, which results in decreased purchasing power of the population so that it cannot meet the nutritional needs of the family.

The results of statistical tests show an effect of energy intake on the incidence of malnutrition in toddlers. The energy source comes from fat, protein, and carbohydrates in food (Adrian \& Wirjatmadi, 2014). Lack of energy will inhibit all physical activities, thinking, and activities that occur in the body. Lack of energy can also be interpreted as a lack of consumption of carbohydrates, fat, and protein that will be used as an energy source as a replacement. If this continues, there will be a lack of protein-energy, which is indicated by marasmus and kwashiorkor (Devi, 2010). The population in the research area has a good food source, however, this food source is not used optimally. Residents who live in the research location prefer to sell most of their crops to meet other needs. As a result, for daily consumption, there is very little nutrition.

This study indicates that there is an effect of protein-energy intake on the incidence of malnutrition in toddlers. This result is in line with research conducted by Lilis, Nurdin, \& Hermiyanti, 2017, which states that protein consumption is a risk factor for malnutrition, which in the long term results in malnutrition in toddlers. Protein consumption is a risk factor for malnutrition. Lack of protein will have an impact on the disruption of growth, development, and productivity. If energy sufficiency is not fulfilled, there will be an overhaul of protein in the body. Its function, which should be growth and building substances, will be hampered by its function, eventually leading to malnutrition, even if too long it will result in malnutrition. Toddlers at Kertosari Health Center have a relatively high eating habit and like to be picky about food. This causes the consumption of both vegetable and animal protein to be inadequate. After toddlers consume snacks such as snacks sold at kiosks, toddlers will return home full, which reduces food consumption for toddlers at home. 


\section{STRADA Jurnal Ilmiah Kesehatan}

DOI: $10.30994 /$ sjik.v9i2.530

ISSN: 2252-3847 (print); 2614-350X (online)

Vol.9 No.2 November 2020 Page.1740-1746

In addition, the consumption of protein-based on the 24-hour food recall shows that protein sources, such as nuts and meat, are still lacking.

The results of this study show that there is an effect of fat intake on the incidence of malnutrition in toddlers. This result is not in line with research conducted by (Virnanda, Dina, \& M. Zen, 2016), which states that fat consumption does not have a significant relationship with toddlers' nutritional status, including malnutrition. The research results indicate that most of the respondents' food is fried, but the intake is small, so that the need for fat is not sufficient from these foods. Apart from those mentioned above, other factors that influence include the fact that most of the respondents are fishermen households, which incidentally have food security status of food-insecure households. The fishermen's families are at risk of food insecurity due to the lack of availability and use of food for consumption. Fishersmen are one that is classified as food insecure due to limited assets, insufficient capital capacity, and access to markets. Some families are also unable to meet the energy needs of the family. This is because the income of fishermen only depends on the fish catch. If the fish catch is increasing, it can be ensured that the food needs are fulfilled, and the remaining income can be used to meet other needs.

There is a significant effect of carbohydrate intake on the incidence of malnutrition among toddlers. This is in line with research conducted by (Lutfiyatul, 2019), which states a relationship between carbohydrate intake and nutritional status in toddlers. In the working area of the Kertosari Puskesmas, most children under five consume 2x carbohydrates, namely at breakfast and in the evening. Based on the results of food weighing and a $2 \times 24-$ hour recall, it was found that the sources of carbohydrates that are often consumed by toddlers are rice, bread, and porridge. The consumption of a variety of foods can reduce the risk of deficiency of certain nutrients in a person. However, for most respondents, carbohydrate intake is less varied and does not meet toddlers' nutritional needs. From the point of view of the intake quality, it is also not sure that it is good. The lack of intake of other macro substances also worsens the condition of toddlers' nutritional deviation.

There is a significant effect of zinc intake on the incidence of malnutrition among toddlers. This is in line with research conducted by (Aas, Gurdani, \& Asep Iwan, 2020), which states a significant relationship between zinc intake and malnutrition status, which results in malnutrition in toddlers. The reason is that most of the parents have a low income. Less family income will reduce people's purchasing power, so that it will affect the community's daily consumption. Essential factors of nutrition can be influenced by the availability of food and knowledge of nutrients (Almatsier, 2010). A person will be able to fulfill adequate consumption if they are able to provide food because the knowledge of nutritional needs supports it. Another factor of family characteristics is the number of individuals in a family. The more family members live in one house, the more food consumption needs will increase. If not followed by the amount of income, the increase in consumption needs will also not be fulfilled (BAPPENAS, 2011). Another cause is the public and health workers' lack of attention to the importance of toddlers' nutritional needs. Health workers never provide education about the importance of nutritional needs in an open manner because they often provide education only through integrated healthcare center for toddlers. As a result, people who do not participate in the integrated healthcare center activities do not know the nutritional information.

There is a significant effect of calcium intake on the incidence of malnutrition among toddlers. This is not in line with research conducted by (Andri Rahmad \& Sri, 2020), which states that there is no significant relationship between calcium intake and poor nutritional status. The study results found that the low intake of calcium and vitamin D was due to 


\section{STRADA Jurnal Ilmiah Kesehatan}

DOI: $10.30994 /$ sjik.v9i2.530

ISSN: 2252-3847 (print); 2614-350X (online)

Vol.9 No.2 November 2020 Page.1740-1746

insufficient milk consumption during weaning and afterward, so that it may be a factor in the high rate of malnutrition. Calcium content in food ingredients can affect linear growth through stimulation of insulin-like growth factor (IGF-1). Consumption of calcium sources in the form of milk also positively affects children's height based on the results of the NHANES survey in 1999-2004 (Keast, Nicklas, \& O'Neil, 2010). So the speculation that arises is that milk consumption is related to the emergence of nutritional problems in toddlers, especially malnutrition and malnutrition, through the mechanism of growthpromoting factors found in calcium, vitamin D, and both. Another contributing factor to low calcium intake is the low economic status, which only allows the respondent's family to meet their food intake with a makeshift menu without thinking about children's nutritional needs according to age. The choice of food variations depends on the money earned on that day. This happens a lot, especially in coastal areas, for example, toddlers in that place most of them have the habit of drinking sugar water every day with a diet mostly processed by fish from fishing. In addition, most respondents have an irregular eating pattern because they are often full of buying pastries and snacks.

\section{CONCLUSION}

The pattern of energy, protein, fat, carbohydrate, zinc, and calcium intake had a significant effect on the number of children under five with malnutrition. The study indicated that the community's food intake pattern around the Kertosari Health Center work area is not optimal, resulting in the toddler's malnutrition. So the advice that can be given by the researchers is that further research is needed on the effect of food intake patterns on malnutrition. The evidence is conducted regarding malnutrition's long-term impact, including that malnutrition can lead to decreased motor development, intelligence, and cognitive value.

\section{REFERENCES}

Aas, A., Gurdani, Y., \& Asep Iwan, P. (2020). Asupan Mikronutrien Dan Riwayat Penyakit Infeksi Pada Balita Stunting Di Uptd Puskesmas Limbangan Kecamatan Sukaraja Kabupaten Sukabumi. Journal of Nutrition College, 9(1), 6-11. https://doi.org/10.14710/jnc.v9i1.24647

Adrian, M., \& Wirjatmadi, B. (2014). Gizi dan Kesehatan Balita Peranan Micro Zinc pada Pertumbuhan Balita. Jakarta: Kencana Prenadamedia Group.

Almatsier, S. (2010). Prinsip Dasar Ilmu Gizi. Jakarta: Gramedia Pustaka Utama.

Andri Rahmad, S., \& Sri, S. (2020). Hubungan Asupan Kalsium dan Zink dengan Kejadian Stunting Pada Siswi SMP Unggulan Bina Insani Surabaya. Media Gizi Kesmas, 9(1), 1. https://doi.org/10.20473/mgk.v9i1.2020.1-9

Arisman. (2009). Gizi dalam Daur Kehidupan. Jakarta: EGC.

Deiby Olivia, R., Nita R, M., \& Nova, H. K. (2018). Hubungan Antara Asupan Energi Dengan Status Gizi Anak Balita Diwilayah Kerja Puskesmas Desa Tambarana Kecamatan Poso Pesisir Utara Kabupaten Poso. Jurnal Kesmas, 7(5).

Devi, N. (2010). Nutritional and Food: Gizi untuk Keluarga. Jakarta: Kompas Media Nusantara. Dinkes Banyuwangi. (2017). Data Jumlah Balita Gizi Buruk (Sangat Kurus) Kabupaten Banyuwangi.

Banyuwangi: Dinas Kesehatan Kabupaten Banyuwangi.

Dinkes Banyuwangi. (2019). Data Jumlah Balita Gizi Buruk (Sangat Kurus) Kabupaten Banyuwangi.

Banyuwangi: Dinas Kesehatan Kabupaten Banyuwangi. 


\section{STRADA Jurnal Ilmiah Kesehatan}

DOI: $10.30994 /$ sjik.v9i2.530

ISSN: 2252-3847 (print); 2614-350X (online)

Vol.9 No.2 November 2020 Page.1740-1746

Fitayani, N. (2014). Hubungan Beban Kerja, Pengetahuan dan Sikap Gizi Ibu, serta Pola Asuh Makan dengan Status Gizi Balita di Kota Bogor. Institut Pertanian Bogor.

Keast, D. R., Nicklas, T., \& O’Neil, C. (2010). Snacking is Associated With Reduced Risk of Overweight and Reduced Abdominal Obesity in Adolescents: National Health and Nutrition Examination Survey (NHANES) 1999-2004. The American Journal of Clinical Nutrition, 92(2), 428-435.

Kemenkes RI. (2011). Standar Antropoemetri Penilaian Status Gizi Anak. Jakarta: Kementrian Kesehatan RI.

Kemenkes RI. (2018). Laporan Hasil Riset Kesehatan Dasar (Riskesdas) Tahun 2018. Jakarta: Kementrian Kesehatan RI.

Lilis, F., Nurdin, R., \& Hermiyanti. (2017). Faktor Risiko Kejadian Gizi Kurang pada Balita Usia 24- 59 Bulan Di Kelurahan Taipa Kota Palu. Jurnal Ilmiah Kedokteran, 4(3), 2959.

Lutfiyatul, A. (2019). Hubungan Pendapatan, Tingkat Asupan Energi dan Karbohidrat dengan Status Gizi Balita Usia 2-5 Tahun di Daerah Kantong Kemiskinan. Amerta Nutrition, 3(3), 183. https://doi.org/10.20473/amnt.v3i3.2019.183-188

Solihin, R., Anwar, F., \& Sukandar, D. (2013). Kaitan antara status gizi, perkembangan kognitif, dan perkembangan motorik pada anak usia prasekolah. Jurnal Penelitian Gizi Dan Makanan, 36(1), 62-72.

Virnanda, A., Dina, R. P., \& M. Zen, R. (2016). Hubungan Asupan Makanan (Karbohidrat, Protein Dan Lemak) Dengan Status Gizi Bayi Dan Balita (Studi Pada Taman Penitipan Anak Lusendra Kota Semarang Tahun 2016). Jurnal Kesehatan Masyarakat (eJournal), 4(3), 261-271. 